\title{
PENGARUH CORPORATE GOVERNANCE, PROFITABILITAS, LEVERAGE, DAN KUALITAS AUDIT TERHADAP REAL EARNINGS MANAGEMENT
}

\author{
Clarissa Maya Devi ${ }^{1}$, Jamaludin Iskak ${ }^{2}$ \\ ${ }^{1}$ Fakultas Ekonomi,Universitas Tarumanagara Jakarta \\ Email : clarissamayadevi@ hotmail.com \\ ${ }^{2}$ Fakultas Ekonomi,Universitas Tarumanagara Jakarta \\ Email : jamaludiniskak.untar@gmail.com
}

\begin{abstract}
ABSTRAK
Penelitian ini bertujuan untuk menguji pengaruh corporate governace, profitabilitas, leverage dan kualitas audit terhadap manajemen laba riil pada perusahaan manufaktur yang terdaftar di BEI selama tahun 2014 sampai dengan tahun 2016. Total sampel yang digunakan dalam penelitian ini sebanyak 63 perusahaan manufaktur. Hasil penelitian menunjukkan bahwa profitabilitas dan kualitas audit berpengaruh terhadap manajemen laba riil, sedangkan corporate governance dan leverage tidak memiliki pengaruh terhadap manajemen laba riil.
\end{abstract}

Kata Kunci : Manajemen Laba Riil, Corporate Governaance, Audit Committee of Accounting Experts, Profitabilitas, Leverage, Kualitas Audit.

\section{PENDAHULUAN}

\section{Latar Belakang}

Setelah periode Sarbanes-Oxley Act (SOX) manajer telah bergeser dari manajemen laba akrual ke manajemen laba riil (Roychowdhury,2006; Braam et al., 2015; Gunny, 2005; Trisnawati et al., 2016).

Praktik manajemen laba riil menggunakan tiga pendekatan, yaitu manipulasi operasi arus kas, biaya produksi dan biaya-biaya diskresioner (Roychowdhury, 2006). Adanya perubahan dari manajemen laba berbasis akrual ke manajemen laba riil memiliki beberapa faktor selain untuk mencapai target laba. Pertama, manipulasi akrual (Gunny, 2005). Kedua, terkait kinerja (Roychowdhury, 2006). Ketiga, akan lebih sulit dideteksi oleh auditor, bahkan auditor yang berkualifikasi dan memiliki keahlian tertentu (Ratmono, 2010)

Penyebab lain yang diduga menyebabkan manajer beralih dari manajemen laba akrual ke manajemen laba riil adalah adanya peningkatan kualitas standar pelaporan keuangan melalui International Financial Reporting Standards (IFRS) (Kurniawati, 2016). Dengan adanya peningkatan kualitas standar pelaporan keuangan, membuat kesempatan manajer untuk melakukan manipulasi laba secara akrual semakin sempit dan dibatasi sehingga manajer beralih dari manajemen laba akrual menjadi manajemen laba riil atau manajemen masih menerapkan keduanya (Zhang, 2007).

Mekanisme corporate governance dalam penelitian ini menggunakan pertemuan komite audit dan audit committee of accounting expert. Nilasari (2012) dan Widyadiningdyah (2001) dalam Wiyadi et al. (2016) menyatakan bahawa leverage berpengaruh terhadap manajemen laba. Ketika manajer tertekan oleh investor yang meminta tingkat keuntungan yang lebih tinggi untuk mengurangi tingkat leverage maka manajemen perusahaan akan termotivasi untuk melakukan real earnings management (manipulasi laba riil). 
Auditor dapat menjaga keandalan dalam laporan keuangan jika auditor memiliki kualitas yang baik. Akibat dari adanya manajemen laba akrual yang dibatasi, maka perusahaan yang memiliki auditor yang berkualitas akan memilih untuk melakukan real earnings management.

Penelitian ini mengacu pada penelitian yang dilakukan oleh Susanto dan Pradipta (2016), tujuan penelitian ini adalah unuk mengevaluasi pengaruh dari corporate governace, profitabilitas, leverage dan kualitas audit terhadap manajemen laba riil pada perusahaan manufaktur yang terdaftar di BEI selama tahun 2014 sampai dengan tahun 2016. Dimana kualitas audit pada penelitian ini dilihat dari jumlah partner dalam KAP. Perlu diketahui bahwa penelitian mengenai real earnings management sangat jarang dilakukan, terutama di Indonesia karena kebanyakan penelitian yang dilakukan adalah menggunakan metode manajemen laba akrual.

Hasil dari penelitian ini diharapkan dapat berguna bagi perusahaan terutama yang berkaitan dengan pemilihan auditor yang menghasilkankualitas audit yang tinggi, baik auditor KAP The Big4 maupun Non Big-4. Selain itu, hasil penelitian ini diharapkan dapat bermanfaat bagi investor sebagai tambahan informasi mengenai kondisi suatu perusahaan sehingga mereka dapat berhatihati sebelum melakukan investasi.

\section{METODE PENELITIAN}

\section{Kajian Teori}

Agency Theory. menimbulkan dua masalah keagenan, yaitu conflict of interest dan asimetri informasi. Jensen dan Meckling (1976). Manajemen Laba. Menurut Scoot (2003), manajemen laba merupakan kebijakan akuntansi yang dipilih manajer untuk memaksimumkan utilitas atau nilai pasar perusahaan dalam rangka mencapai tujuan tertentu.Manajemen laba riil (real earnings management). Roychowdhury (2006) mendefinisikan manajemen laba riil (real earnings management) sebagai tindakan-tindakan manajemen yang menyimpang dari praktek bisnis perusahaan yang normal,

Corporate Governance merupakan konsep yang didasarkan pada teori keagenan, yang diharapkan dapat berfungsi untuk mengurangi adanya manipulasi laba oleh manajer sehingga kinerja yang dilaporkan mencerminkan keadaan ekonomi perusahaan yang sebenarnya. Pertemuan Komite Audit. Pertemuan komite audit merupakan tempat direksi untuk membahas proses pelaporan keuangan dan tempat proses monitoring pelaporan keuangan yang terjadi (Mohamad Nor et al., 2010)..Audit Committee of Accounting Expert. Anggota komite audit yang memiliki latar belakang pendidikan akuntansi dan memiliki pengalaman kerja di bidang akuntansi dipandang dapat meningkatkan kualitas dari laporan keuangan perusahaan dalam hal ini kaitanya dengan real earnings management (Wardhani dan Joseph, 2010 dalam Susanto dan Pradipta, 2016).

Profitabilitas. Profitabilitas menunjukkan keberhasilan perusahaan dalam menghasilkan keuntungan. Return on Asset (ROA) digunakan untuk mengukur kemampuan manajemen dalam memperoleh keuntungan atau laba secara keseluruhan (Wiyadi et al., 2016).

Leverage. Seperti yang diketahui bahwa leverage bisa digunakan dengan harapan dapat meningkatkan return kepada para pemegang saham. Namun ketika perusahaan memiliki tingkat leverage yang tinggai maka investor juga akan meminta return yang tinggi karena risiko yang dihadapi oleh investor jauh lebih besar ketika perusahaan tersebut tidak mampu membayar hutangnya dan mengalami kebangkrutan. Menurut Wiyadi et al. (2016) rasio leverage mengukur 
sejauh mana perusahaan mendanai usahanya dengan membandingkan antara dana sendiri yang telah disetorkan dengan jumlah pinjaman dari para kreditur.

Kualitas Audit. De Angelo (1981) dalam Saripudin et al. (2012) mendefinisikan kualitas audit sebagai kemungkinan (probability) dimana seorang auditor menemukan dan melaporkan tentang adanya suatu pelanggaran dalam sistem akuntansi kliennya. Jumlah Partner. Berdasarkan Standar Pengendalian Mutu nomor 1 tentang Pengendalian Mutu bagi Kantor Akuntan Publik yang Melaksanakan Perikatan Asurans (Audit, Reviu, dan Perikatan Asurans Lainnya) dan Perikatan Selain Asurans disebutkan bahwa rekan perikatan merupakan rekan atau individu lain dalam KAP yang bertanggung jawab atas perikatan dan pelaksanannya, serta kesimpulan yang dihasilkan. Jumlah partner dalam suatu Kantor Akuntan Publik dapat mempengaruhi kualitas audit dari suatu laporan keuangan.

Keefektivitasan komite audit dalam melaksanakan peran pengawasan atas proses pelaporan keuangan dan pengendalian internal juga memerlukan rapat secara rutin (Pratiwi dan Meiranto, 2013). Pramudji et al., (2010) dan Nasution dan Setiawan (2007) menunjukkan bahwa frekuensi rapat komite audit tidak mempengaruhi manajemen laba. Berbeda dengan penelitian yang dilakukan oleh Anggarini (2010) dalam Pratiwi dan Meiranto (2013) yang menyatakan bahwa dengan melakukan pertemuan secara periodik, komite audit dapat mencegah dan mengurangi kemungkinan terjadinya kesalahan dalam pembuatan keputusan oleh manajemen. Defond et al. (2005) menunjukkan bahwa komite audit yang memiliki keahlian dibidang akuntansi dan keuangan merupakan faktor yang penting untuk menghambat terjadinya manajemen laba. Penelitian lain yang dilakukan Susanto (2014), Nasution dan Setiawan (2017) menyatakan bahwa keahlian komite audit dalam bidang akuntansi dan keuangan tidak berpengaruh terhadap manajemen laba. Hal ini menunjukkan bahwa pembentukan komite audit dengan kompetensi di bidang akuntansi dan keuangan hanya bersifat wajib terhadap peraturan.

Penelitan tentang profitabiitas dan leverage juga telah banyak dilakukan oleh, Wiyadi et al. (2016) Madli (2014) ,Darmawanti (2003) dan Astuti (2004) dalam Guna dan Herawaty (2010).

Seperti yang diketahui bahwa manajemen laba akrual dan manajemen laba riil memainkan peran substitusi. Auditor yang mampu memberikan kualitas audit yang baik akan memaksa manjemen perusahaan untuk menghentikan manajemen laba akrual yang dilakukannya karena perusahaan yang tetap melakukan manajemen laba akrual akan terancam tidak memperoleh opini wajar tanpa pengecualian (Setiawan dan Lestari, 2014). Namun disisi lain, kualitas auditor yang tinggi akan meningkatkan real earnings management. 
Model penelitian dalam penelitian ini dapat digambarkan seperti dibawah ini :

Corporate Governance

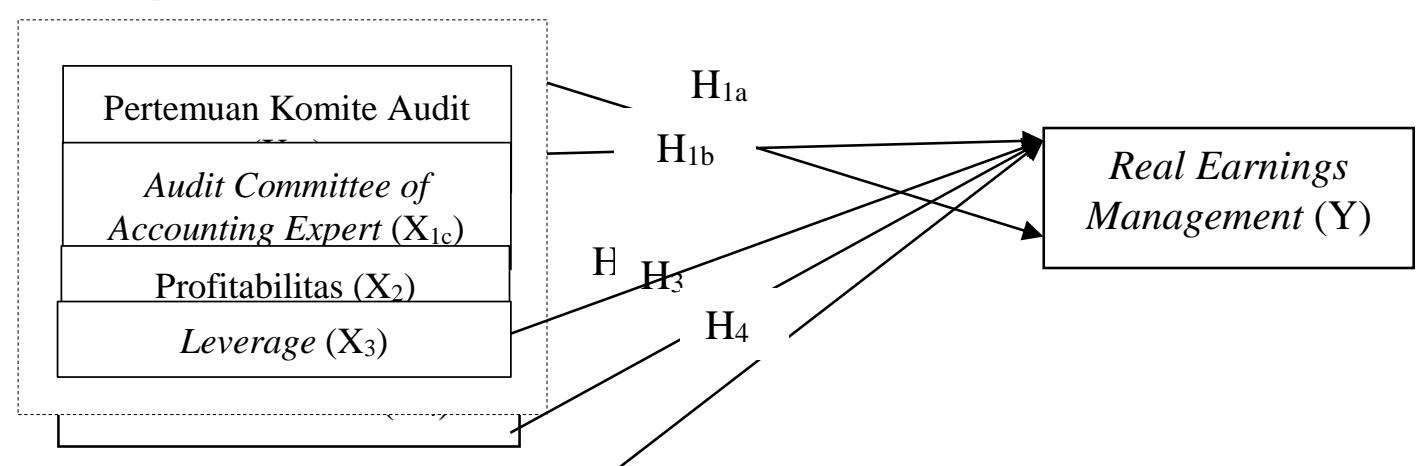

Ganboar 1. Model Penelitian

Hipotesis dari model penelitian yang dibangun di atas adalah sebagai berikut :

$\mathrm{H}_{1 \mathrm{a}}$ :. $\quad$ Corporate governance yang diproksikan dengan pertemuan komite audit berpengaruh positif terhadap real earnings management.

$\mathrm{H}_{1 \mathrm{~b}}$ :- $\quad$ Corporate governance yang diproksikan dengan audit committee of accounting expert berpengaruh positif terhadap real earnings management.

$\mathrm{H}_{2}$ :. $\quad$ Profitabilitas berpengaruh positif terhadap real earnings management.

$\mathrm{H}_{3} \quad$ : Leverage berpengaruh negatif terhadap real earnings management.

$\mathrm{H}_{4}$ : $\quad$ Kualitas audit yang diproksikan dengan jumlah partner berpengaruh positif terhadap real earnings management.

\section{Metodologi}

Objek Penelitian. Objek penelitian ini adalah perusahaan manufaktur yang terdaftar di BEI (Bursa Efek Indonesia) pada periode 2014-2016, yang laporan keuangannya didapat dari www.idx.co.id. Pemilihan sampel dilakukan secara purposive sampling dengan kriteria-kriteria yang ditentukan dalam pengambilan sampel penelitian ini. Jumlah data yang memenuhi syarat adalah 63 perusahaan.

Variabel operasional dalam penelitian ini terdiri dari real earnings management, pertemuan komite audit, audit committee of accounting expert, profitabilitas, leverage, dan kualitas audit yang diproksikan dengan jumlah partner. Dalam penelitian ini, real earnings management diukur melalui pendekatan abonormal cash flow operation dengan formula :

$$
\begin{gathered}
\text { Real Earnings Management }=\text { CFOt /At }-1=\alpha_{0}+\beta_{1}(1 / \text { At }-1)+\beta_{2}(\text { St } / \text { At }-1) \\
+\beta_{3}(\Delta \mathrm{St} / \text { At }-1)+\varepsilon t
\end{gathered}
$$

Sedangkan pertemuan komite audit dalam penelitian ini diukur dari berapa kali komite audit melakukan rapat dalam setahun.

Pertemuan Komite Audit = Jumlah Rapat Komite Audit Selama Satu Tahun 
Audit Committee of Accounting Expert. Dalam penelitian ini Audit Committee of Accounting Expert diukur dari jumlah anggota komite audit dengan latar belakang pengalaman kerja dibidang akuntansi maupun keuangan.

Audit Committee of Accounting Expert = Jumlah Anggota Komite Audit Yang Memiliki Keahlian Dibidang Akuntansi atau Keuangan.

Profitabilitas. Dalam penelitian ini profitabilitas diwakili oleh Return On Asset (ROA) yang diukur dengan membandingkan laba bersih setelah pajak dan bunga dengan total aset.

$$
\text { Return On Asset }=\frac{\text { Earnings After Interest and Tax }}{\text { Total Asset }}
$$

Dalam penelitian ini leverage diukur dengan membandingkan total kewajiban dengan total aset.

Leverage $=\frac{\text { Total Liability }}{\text { Total Asset }}$

Kualitas Audit. Dalam penelitian ini, kualitas audit diwakili oleh jumlah partner audit dari suatu KAP.

Kualitas Audit = Jumlah Partner Audit Suatu KAP

Dalam penelitian ini menggunakan Uji Statistik Deskriptif untuk menguji data sampel, kemudian melakukan uji asumsi klasik yang terdiri dari Uji Multikolineritas, Uji Heteroskedastisitas, dan Uji Autokorelasi. Sedangkan uji hipotesis menggunakan Uji t dan Uji F, Uji Koefisien Determinasi, dan Uji Koefisien Korelasi.

\section{HASIL DAN PEMBAHASAN Hasil Uji Statistik}

Hasil statistik deskrptif untuk periode 2014-2016 menunjukkan bahwa nilai mean untuk real earnings management sebesar 0.000003 dengan nilai minimum dan maksimum sebesar -0.4235 dan 0.4544, dan standar deviasi sebesar 0.1224081. Pertemuan komite audit memiliki nilai minimum dan maksimum sebesar 2 dan 36 dengan nilai mean sebesar 6.58, dan standar deviasi sebesar 5.514. Audit Committee of Accounting Expert memiliki standar deviasi sebesar 0.781 dan nilai minimum dan maksimum sebesar 1 dan 4 serta nilai mean sebesar 2.17. Profitabilitas memiliki memiliki nilai mean sebesar 0.111841 dan standar deviasi sebesar 0.1323105 dengan nilai minimum dan maksimum sebesar 0.0004 dan 0.8879 . Leverage memiliki nilai mean sebesar 0.1816138 dan standar deviasi sebesar 0.1816138 dengan nilai minimum dan maksimum sebesar 0.0496 dan 0.8387 . Kualitas audit memiliki nilai rata-rata sebesar 19.50 dan standar deviasi sebesar 8.509 dengan nilai minimum dan maksimum sebesar 1 dan 35 .

Uji Asunsi Klasik. Uji asumsi klasik dilakukan sebelum uji hipotesis dilakukan. Uji Normalitas. Penelitian ini menggunakan uji normalitas dengan One-Sample Kolmogorov-Smirnov. Dalam penelitian ini, menunjukkan bahwa asymp. sig (2-tailed) bernilai $0.156>0.05$, maka dapat disimpulkan bahwa data berdistribusi normal dan memenuhi asumsi normalitas. Uji selanjutnya adalah Uji Multikolineritas. Uji ini digunakan untuk melihat ada tidaknya multikolineritas yang 
dapat dilihat dari nilai tollerance dan VIF. Dari hasil pengolahan data diperoleh nilai tollerance $>$ 0.10 dan nilai VIF < 10 untuk semua variabel sehingga dapat disimpulkan bahwa model dalam penelitian ini tidak terjadi multikolinearitas. Uji berikutnya adalah Uji Heteroskedastisitas yang bertujuan untuk melihat ada tidaknya masalah heteroskedastisitas yang dilihat dari nilai signifikansinya. Dimana, hasil pengolahan data dalam penelitian ini menunjukkan nilai signifikansi untuk variabel profitabilitas dan leverage $<0.05$ sehingga dapat disimpulkan bahwa terjadi masalah heteroskedastisitas untuk variabel profitabilitas dan leverage. Uji asumsi klasik yang terakhir adalah Uji Autokorelasi yang mana digunakan untuk melihat ada tidaknya korelasi antara kesalahan pengganggu pada periode $t$ dengan kesalahan pengganggu pada periode $\mathrm{t}-1$ (sebelumnya). Hasil pengolahan data menunjukkan bahwa nilai sig sebesar $0.834>0.05$ sehingga dapat disimpulkan tidak terjadi autokorelasi dalam model regresi.

Hasil analisis regresi berganda, dapat disimpulkan dengan persamaan model regresi berikut : $\mathrm{REM}=-0.074-0.001 \mathrm{PK}+0.001 \mathrm{ACA}+0.298 \mathrm{PROF}-0.050 \mathrm{LEV}+0.003 \mathrm{KA}+\mathrm{e}$

Dari persamaan diatas, nilai konstan sebesar -0.074. Hal ini menyatakan bahwa nilai real earnings management tidak dipengaruhi oleh variabel-variabel independen. Nilai koefisien regresi utuk Pertemuan Komite Audit bernilai -0.001 artinya setiap peningkatan Pertemuan Komite Audit (PK) sebesar satu (1) satuan akan menurunkan real earnings management sebesar -0.001 dengan asumsi variabel independen yang lain adalah konstan. Nilai koefisien regresi Audit Committee of Accounting Expert sebesar 0.001 artinya setiap peningkatan Audit Committee of Accounting Expert (ACA) sebesar satu (1) satuan akan menaikan real earnings management sebesar 0.001 dengan asumsi variabel independen yang lain adalah konstan. Nilai koefisien regresi Profitabilitas sebesar 0.298 artinya setiap peningkatan Profitabilitas (PROF) sebesar satu (1) satuan akan menaikan real earnings management sebesar 0.298 dengan asumsi variabel independen yang lain adalah konstan. Nilai koefisien regresi untuk Leverage adalah sebesar -0.050. Hal ini menandakan setiap peningkatan Leverage (LEV) sebesar satu (1) satuan akan menurunkan real earnings management sebesar -0.050 dengan asumsi variabel independen yang lain adalah konstan. Nilai koefiisen regresi untuk Kualitas Audit adalah sebesar 0.003 artinya setiap peningkatan variabel Kualitas Audit (KA) sebesar satu (1) satuan akan menaikan real earnings management sebesar 0.003 dengan asumsi variabel independen yang lain adalah konstan.

Uji t : Untuk menguji hipotesis nol ditolak atau diterima, titik tolakny adalah bila nilai $p$-value $t$ test $<$ atau $>0.05$, artinya jika nilai signifikansi dari variabel independen dibawah 0.05, maka $\mathrm{H} 0$ ditolak dan Ha diterima dan sebaliknya. Hasil uji ini dapat dilihat pada tabel dibawah ini:

Tabel 1. Koefisien Regresi 


\begin{tabular}{|c|c|c|c|c|c|c|}
\hline \multicolumn{7}{|c|}{ Coefficients $^{a}$} \\
\hline \multirow{2}{*}{\multicolumn{2}{|c|}{ Model }} & \multicolumn{2}{|c|}{ Unstandardized Coefficients } & $\begin{array}{l}\text { Standardized } \\
\text { Coefficients }\end{array}$ & \multirow[b]{2}{*}{$t$} & \multirow[b]{2}{*}{ Sig. } \\
\hline & & $\mathrm{B}$ & Std. Error & Beta & & \\
\hline 1 & (Constant) & -.074 & .037 & & -1.987 & .048 \\
\hline & Meeting & -.001 & .001 & -.049 & -.728 & .468 \\
\hline & Expert & .001 & .010 & .005 & .075 & .940 \\
\hline & Profitabilitas & .298 & .063 & .322 & 4.731 & .000 \\
\hline & Leverage & -.050 & .046 & -.075 & -1.107 & .270 \\
\hline & Kualitas_Audit & .003 & .001 & .237 & 3.404 & .001 \\
\hline
\end{tabular}

a. Dependent Variable: REM

Sumber: Hasil Olah Data dengan SPSS, 2017

Uji korelasi (R). Dalam penelitian ini menunjukkan nilai $\mathrm{R}$ sebesar 0.469 . Hal ini menunjukkan bahwa hubungan antara variabel independen dengan variabel dependen adalah sedang. Dan Uji Koefisien Determinasi (Adjusted R-Square) yang digunakan dalam penelitian ini digunakan untuk mengetahui besarnya presentase sumbangan variabel independen secara bersama-sama terhadap variabel dependen yang ditunjukkan dengan angka sebesar 0.199. Jadi, dapat disimpulkan bahwa besarnya variasi dari variabel dependen yang dapat dijelaskan oleh variabel independen dalam model penelitain ini adalah 19.9\%. Sedangkan Uji F digunakan untuk melihat apakah model regresi layak atau tidak untuk digunkan dalam penelitian. Hasil Uji F menunjukkan bahwa nilai signifikansi sebesar $0.000<0.05$ dari nilai yang telah ditetapkan sehingga dapat disimpulkan bahwa model regresi layak atau fit untuk digunakan dalam pengujian data.

\section{Diskusi}

Hasil pengujian statistik dengan uji parsial menunjukkan bahwa variabel Pertemuan Komite Audit tidak berpengaruh positif terhadap Real Earnings Management. Hasil pengujian statistik dengan uji parsial menunjukkan bahwa variabel Audit Committee of Accounting Expert tidak berpengaruh positif terhadap Real Earnings Management. Hasil pengujian statistik dengan uji parsial menunjukkan bahwa variabel Profitabilitas berpengaruh positif terhadap Real Earnings Management. Hasil pengujian statistik dengan uji parsial menunjukkan bahwa Variabel Leverage tidak berpengaruh negatif terhadap Real Earnings Management. Hasil pengujian statistik dengan uji parsial menunjukkan bahwa Variabel Kualitas Audit yang diproksikan dengan jumlah partner berpengaruh positif terhadap Real Earnings Management.

\section{KESIMPULAN DAN SARAN}

\section{Penutup}

Berdasarkan hasil pengujian data dalam penelitian ini, real earnigs management yang dilakukan pada perusahaan manufaktur di Indonesia yang terdaftar di BEI periode 2014-2016 menunjukkan bahwa real earnings management yang dilakukan dipengaruhi oleh faktor profitabilitas dan kualitas audit. Hal ini terjadi kemungkinan karena profitabilitas perusahaan yang baik menunjukkan kinerja perusahaan yang baik sehinga para manajer tidak akan termotivasi untuk melakukan manajemen laba riil dan semakin banyak audit partner maka semakin banyak diskusi dan audit tools yang digunakan untuk mengaudit suatu perusahaan sehingga mampu membatasi adanya praktik manajemen laba secara riil.

\section{Saran}


Saran yang dapat diberikan untuk melakukan penelitian selanjutanya yaitu, melakukan penelitian terhadap perusahaan terbuka Non-Manufaktur dengan menambah variabel-variabel independen baru untuk menambah variasi, dan dapat menggunakan variabel moderasi untuk melihat apakah dengan menggunakan variabel moderasi akan memperkuat atau memperlemah hubungan anatara varaibel independen terhadap real earnings management sebagai variabel dependen.

\section{REFERENSI}

Andriyani, Rida, dan Muhammad Khafid. (2014). Analisis Pengaruh Leverage, Ukuran Perusahaan Dan Voluntary Disclosure Terhadap Manipulasi Aktivitas Riil. Accounting Analysis Journal. http://journal.unnes.ac.id/sju.index.php/aa.

Braam, G., Nandy, M., Weitzel, Ut., and Lodh, S. (2015). Accrual-based and Real Earnings Management and Political Connection. Inter-national Journal of Accounting, Vol. 50. No.2. Hlm. 111-141.

Defond, M. L., Hann, R. N., \& Hu, X. (2005). Does the market value financial expertise on audit committees of boards of directors? Journal of accounting research. Vol.42. No.2. Hlm. 153-193.

FCGI. (2002). Corporate Governance: Tata Kelola Perusahaan. Edisi Ketiga. Jakarta.

Guna, Welvin I dan Arleen Herawaty. (2010). Pengaruh Mekanisme Good Corporate Governace, Independensi Auditor, Kualitas Audit, dan Faktor Lainnya Terhadap Manajemen Laba. Jurnal Bisnis dan Akuntansi. Vol.12. No.1. April 2010. Hlm.53-68.

Gunny. (2005). What Are the Consequences of Real Earnings Management? Working Paper. University of Colorado at Boulder.

Institut Akuntan Publik Indonesia (IAPI). (2013). Standar Pengendalian Mutu No.1. Pengendalian Mutu Bagi Knator Akuntan Publik Yang Melaksanakan Perikatan Asurans (Audit, Reviu, dan Perikatan Asurans Lainnya) dan Perikatan Selain Asurans.

Jansen, Michael. C., dan Mackling, William H. (1976). Theory of The Firm : Managerial Behavior Agency Cost and Awnership Structure. Journal of Financial Economics. Vol.3. No.4. Hlm. 305-306.

Kurniawati. (2016). Pengaruh Kualitas Audit Terhadap Kecenderungan Perubahan Perilaku Manajemen Laba : Studi Empiris Pada Perusahaan Manufaktur Yang Terdaftar di Bursa Efek Indonesia Periode 2012-2015. Jurnal Akuntansi Bisnis. Vol.10. No.1.

Mohamad-Nor et al., (2010). Corporate Governance and Audit Report Lag in Malaysia. Asian Academy of Management Journal of Accounting and Finance. AAMJAF, Vol. 6. No. 2, 57 84.

Nasution, Marihot dan Doddy Setiawan. (2007). Pengaruh Corporate Governance Terhadap Manajemen Laba. Simposisum Nasional Akuntansi X, Makasar.

Pamudji, Sugeng and Aprillya Trihartati. (2010). Pengaruh Independensi dan Efektivitas Komite Audit Terhadap Manajemen Laba. Jurnal Dinamika Akuntansi. Vol.2. No.1.

Pratiwi, Yudhitya Dian dan Wahyu Meiranto. (2013). Pengaruh Penerapan Corporate Governance Terhadap Earnings Management Melalui Manipulasi Aktivitas Riil. Diponegoro Journal Of Accounting. Vol. 2. No.3. Hlm. 1-15.

Ratmono, Dwi. (2010). Manajemen Laba Riil dan Berbasis Akrual : Dapatkah Auditor Yang Berkualitas Mendeteksinya? Simposium Naional Akuntansi XIII, Purwokerto.

Roychowdhury, S. (2006). Earnings Management Through Real Activities Manipulation. Journal of Accounting and Economics. 42 : 335-370. 
Saripudin, Netty Herawaty, dan Rahayu. (2012). Pengaruh Independensi, Pengalaman, Due Professional Care, dan Akuntabilitas terhadap Kualitas Audit (Survei terhadap Auditor KAP di Jambi dan Palembang). E-Jurnal Binar Akuntansi. Vol. 1 No.1.

Scoot, William R. (2003). Financial Accounting Theory $\left(3^{\text {th }}\right.$ ed). Unversity of Waterloo. Prentince Hall International, Inc.

Setiawan, Thomas Julianto dan Jenjang Sri Lestari. (2014). Pengaruh Kualitas Audit Terhadap Real Earnings Management Pada Perusahaan Manufaktur Yang Terdaftar di Bursa Efek Indonesia. http://e-journal.uajy.ac.id/6745/1/jurnal.

Susanto, Yulius Kurnia. (2014). Audit Committees and Earnings Management: Evidence From Indonesia Manufacturing Industry. Paper presented at International Conference on Entrepreneurship and Business Management (ICEBM 2014). Penang, Malaysia, November 6-7.

Susanto, Yulius Kurnia dan Arya Pradipta. (2016). Corporate Governance and Real Earnings Management. International Journal of Business, Economics, and Law. Vol.9. No.1.

Trisnawati, Rina., Wiyadi dan Noer Sasongko. (2016). Pengukuran Manajemen Laba:PendekatanTerintegrasi $\quad$ http://sna.akuntansi.unikal.ac.id/makalah/039-AKPM71.pdf.

Wiyadi., Rina Trisnawati., Noviana Puspitasari., dan Noer Sasongko. (2016). Pengaruh Asimetri Informasi, Leverage dan Profitabilitas Terhadap Manajemen Laba Riil Pada Perusahaan Manufaktur di Indonesia. The $3^{\text {nd }}$ University Research Coloquium.

Zhang, A. (2007). "Evidence on the Tradeoff Between Real Manipulation and Accrual Manipulation”. Working Paper. Hongkong University of Science and Technology. 